\title{
COOPERATION AS ONE OF THE CHARACTERISTIC FEATURES OF INCLUSION
}

\author{
Jiří Havel \\ Jana Kratochvílová
}

\begin{abstract}
We perceive communication, cooperation, application of differentiation and individualization, maximum expectation from pupils and respect among participants of education as characteristic features of inclusive education. In this paper we carry out an qualitative and quantitative analysis of data gained from six selected indicators relating to the cooperation in Czech primary schools, which we perceive as a necessary condition for inclusion. As a research tool we used the Czech version of the questionnaire Framework for Self-evaluation of Conditions of Education 2007 from which we have selected criteria specifying the characteristics of cooperation that we have analyzed.
\end{abstract}

\section{Keywords}

Primary education, special educational needs, inclusion, cooperation.

\section{INTRODUCTION}

Education supporting inclusion requires stimulating and friendly school environment, mainly based on mutual respect among teaching staff and pupils and an appropriate method of communication among pupils and teachers. At the same time, it aims both at developing of the inner potential of each pupil and at supporting of integration into social environment in a classroom and ensuring a safe climate. To the above mentioned aspects of inclusion we also added a focus on the analysis of obtained data through the research with the following aim: to determine what conditions in education the teachers create for their pupils in primary education from the view of inclusion and how they evaluate these conditions by themselves and verbalize them. The research is a part of the extended research project Special Needs of Pupils in the Context of the Framework Educational Program for Basic Education, implemented at the Masaryk University in Brno (the main resolver is prof. PhDr. Marie Vítková, CSc.).

Our main goal was to describe the form of inclusion at primary school not only in a project of inner formal curricula, but especially in its inner form of realization. Emphasis is placed on how the teachers and the other members of school staff perceive and interpret inclusion. We formulated these research questions: 
1. How do the teachers evaluate the level of ensuring conditions of an inclusive education in their school? (Quantitative approach)

2. How do the teachers understand the offered indicators of inclusion?

3. What arguments do the teachers choose for understanding of their evaluation? (Qualitative approach)

4. What arguments do the teachers use for improving the situation? (Qualitative approach)

Upon ascertainment results, we defined the next experimental question:

5. What are the characteristic marks of inclusive education?

Given that cooperation among the participants of the educational process is considered as one of the features of inclusive education (which cannot be separated from other features characterizing inclusion) we present at the beginning of this paper the overall concept of research, followed by the findings focused on cooperation.

\section{THEORETICAL FRAMEWORK}

Concepts of inclusion and integration are widely discussed issues across many countries and their use is considered according to their meaning.

The current data conception of inclusion in education comes out from many research works, especially external. The researches of inclusive environment in England are connected with Booth (1981), Dyson (1990), Ainscow (1999, 2005), Booth \& Ainscow (1998). Especially between external researches it is worth mentioning the studies of Ainscow (2000), which is concentrated on inclusive practice in the UK, Brazil, China, India, Rumania, Spain and Zambia and findings from researches Teaching and Learning Research Program (TLRP) in the United Kingdom (www.tlrp.org). Emphasis is placed also on the action research by O'Hanlon (2003).

In the Czech Republic the written work titled Special Needs of Pupils in the Context of the Framework Educational Program for Basic Education (http:// www.ped.muni.cz/wsedu/index.php?p=vyzkumny-zamer) notably contributed to the conception of inclusive education of findings from a research intention at the Faculty of Education of Masaryk University in Brno.

While in relation to the student inclusion means to be part of the local community from the beginning, integration means that the aim is to integrate the pupil back into mainstream education, because at some point he/she had been earmarked (Watkins, 2009, p. 81). Inclusion is now understood as a human rights issue that immediately concerns a wider range of learners than those of students with special educational needs (European Agency for Development in Special Needs Education, 2011). 
Some complications are perceptible in the terminology of typology of six different ways of thinking about inclusion (Ainscow, 2006), which influence the educational system of each country. When we talk about inclusion, we mean its wider process of conception. In defining this concept, we perceive it as an on-going process aimed at offering quality education for all, while respecting diversity and the different needs and abilities, characteristics and learning expectations of the students and communities and eliminating all forms of discrimination (UNESCO-IBE, 2008; Obiakor, 2012). We combine this concept with another one - the quality of student life (see also the components of quality - the cognitive development of the learner and the role of education in promoting values and attitudes of responsible citizenship and/or creative and emotional development in the UNESCO Policy Guidelines on Inclusion in Education (2009).

Also the Czech educational system is on its way to inclusion. The Czech schools have entered the idea of autonomy in the legal, economic and educational areas. All changes have been enshrined in many legislative documents. Educational autonomy was supported by the legal definition of the so-called two-level syllabus. The syllabus at the national level in primary education introduces the Framework Educational Program for Basic Education which is compulsory and simultaneously the starting point for the development of school curricula. According to their current conditions, visions and objectives, the schools can be influenced by them. The national curriculum emphasizes learning strategies that support the development of cooperation among pupils and defines cooperation as one of the key competencies.

\section{RESEARCH - METHODOLOGY}

For analyzing the aspects mentioned above we used the quantitative and qualitative approaches. As a fundamental research tool we used the Czech version of the questionnaire Framework for Self-evaluation of Conditions of Education (modified version of the British original Index for Inclusion - T. Booth \& M. Ainscow, 2002) and the qualitative content analysis of the syllabus from eight schools.

Reasons forchoosing the questionnaire were to be:

" To verify usability of the Czech version of the Index for Inclusion from year 2002, on domestication in the framework of the project Inclusive sharing perhaps 20 Czech basic schools.

It starts from the access to inclusion like the fundamental access to education (Ainscow, 2006; Arnesen, Alen, \& Simonsen, 2009) and includes indices of inclusion that concern culture and school clime, significance of inclusive education and tuition practice.

- It provides quantitative and qualitative data. 
"It leads the criticism to tag arguments on, to add its evaluation on the spectrum and at the same time to tag the authority of inclusion on school. Its using is then in accordance with a procession conception of inclusion.

According to the general quantitative analysis, we obtained information from the seven-point scale ( 1 - not at all, 7 - absolutely yes) where the criteria of inclusion are evaluated as the best, the worst, and among which are the biggest differences. According to the nature of the questionnaire we obtained a set of arguments for sub-criteria, which justify their ratings and also an idea about how to improve the conditions for inclusion (Kratochvílová, Havel \& Filová, 2009). For analysis of arguments we used the method of content analysis.

After this first analysis, we set the inclusion goal: to further analyze the basic characteristics of inclusion at schools, which are necessary for an inclusive environment. Relating to a difference of school environment, it is not easy to define unambiguous principles of inclusion. We came out of wider signs of inclusion (Ainscow, 2006, p. 25) and principles of inclusion (Janebová-Kučerová, 2008, p. 14), from examples of a good practice (Peters, 2004, p. 10) and from basic results of contextual analyses of school arguments and indicators from Framework for Self-evaluation of Conditions of Education. We defined five principles of inclusion.

Basic characteristics we defined as follows:

1. Communication - the fact how much schools ensure the conditions for inclusive education, it depends on communication among all members of the community to which education relates. It is not just about communication between teachers and pupils, pupils themselves, teachers themselves, but also about the broader communication beyond the school. The level of communication affects mainly the climate of class and school and all the relations with the external environment.

2. Cooperation - one of the features of inclusive schools is cooperation at all levels: cooperation among pupils, cooperation among the educational staff, cooperation among the school management and other workers, cooperation with the external environment, especially with professionals who assist during integration of children with special educational needs in the schools and classes. Cooperation with parents is also very important. In the analysis of the conditions of inclusion, we have focused on cooperation among pupils and cooperation among adults who directly influence the education of pupils.

3. Application of differentiation and individualization in education - ensures that all pupils can learn optimally and can achieve their maximum despite their differences. The starting point of individualization and differentiation is a diagnostic activity of the teacher in the classroom leading to define the learning objectives (according to individuals). The teacher tries to achieve 
these objectives in cooperation with pupils through the educational content at a specific time and with using selected teaching strategies and appropriate evaluation of teaching. A teacher can differentiate education in terms of content, timing, methodology and organization.

4. Maximum expectation from pupils - in developing and creating (supporting of all qualities of pupils' life) conception of education, it is necessary that each pupil is perceived as a person and that teachers work with statements in a sensitive way, whom they express their expectations towards a child.

5. Respect among pupils and school staff - respect is generally unconditional acceptance of each individual. Acceptance and respect due to the fact that I am, I exist. In inclusive school there is required the respect at all possible levels: pupil - pupil, pupil - teacher, teacher - teacher, teacher - non-teacher, school principal - employee etc. This respect affects the climate of the class, school climate and contributes to the understanding differences among individuals and different groups.

During the next stage of the research we focused on the description of five aspects of inclusion in the schools. For each category mentioned above, as first we chose the criteria selected from all three parts of the questionnaire Framework for Self-evaluation Conditions of Education that described them. After this step we carried out a clear quantitative evaluation of individual criteria. Then we commented on the obtained values by examples from a qualitative analysis of teachers' argumentation (more in Kratochvílová, Havel \& Filová, 2011).

\section{RESEARCH SAMPLE}

Teachers of primary school attended this research process; finally there were eight elementary schools. It was a deliberate choice in which we focused on equitable representation of rural or urban schools. Although the first phase of original research sample was formed by ten schools, we were not able to retrieve correctly completed materials from two chosen subjects. Positive contrast that was preserved was a balanced representation of elementary urban schools and rural schools. The urban schools are mostly fully organized, there are also two kindergartens integrated in. The number of students is from 217 to 649.

In contrast, there were also three schools that explicitly stated they educate foreigners and children of various ethnicities, which also brought a wide range of social and cultural background of pupils. The number of teachers is between 16 and 41 . Considering the schools with an integrated kindergarten, the number of teachers is also increased due to all the teachers of the kindergarten. Simultaneously, it is noticed that there is nearly $100 \%$ of the qualified teachers at schools in Brno (in some cases teachers are still studying).

Pedagogical enthusiasm and a wide participation in the actions of teachers' lifelong education were also noticed. On the contrary, there were not noticed 
any specific activities relating to the readiness of teachers working with pupils with special educational needs (SEN) or with exceptionally gifted pupils.

In accordance to rural schools, there was one fully organized school and three schools were listed among small schools. In all the mentioned subjects there were also kindergartens integrated in! The number of pupils was between 45 to 165 pupils. In the view of the social and cultural background of children it dealt with a much more homogenous environment than at contemporary urban schools in general.

The number of teachers was quoted between 3 and 13. It is necessary to add one or two teachers from kindergarten. Qualification varies between 90 and $100 \%$ (and some teachers are still studying further education). Even the rural schools with high activity at events of teachers' lifelong education do not focus on specific activities towards working with pupils with SEN or with exceptionally gifted pupils. Some of the observed rural schools are directly involved in the organization and methodological guidance of further education of teachers.

We are aware that - considering the range of the research sample - a generalization of our findings as a description of common situation at primary schools is not possible. In the terms of scope in this paper we present one of the features of inclusive school-cooperation.

\section{FINDINGS}

One of the features of inclusive schools is cooperation at all levels: cooperation among pupils, cooperation among the educational staff, cooperation among the school management and other workers, cooperation with the external environment, especially with professionals who assist during integration of children with special educational needs into schools and classes. Cooperation with parents is also important. In the analysis of the conditions of inclusion, we have focused on cooperation among pupils and cooperation among adults who directly influence the education of pupils.

\section{A. Cooperation among the educational staff and other experts}

Creating a school culture and climate supporting the inclusion is very closely related to a level of professional educational communication. Cooperation is also very closely linked with it. In the broader definition, it is not only the cooperation among the educational staff, but also the cooperation of all the staff and at the same time also the cooperation within the microenvironment of the school. In particular, cooperation with parents, members of the local community and many experts who can contribute to the creation of an inclusive school environment. From the analysis of educational programs at primary schools it was found out, that teachers most often ask for a methodological support of the staff of pedagogical and psychological counseling centres (pedagogic psychological advice centres) and very closely cooperate with special pedagogues. 
Three large urban schools have comprehensive school counseling departments. Apart from a school counselor and a special pedagogue they also have a well trained teacher for prevention and one of these schools directly employs a school psychologist. Situation in the functioning of the in one case school counseling centre is illustrated by a special educational centre that provides a comprehensive special educational care directly at school. One school also mentioned all benefits of such a department relating to the integration of different cultural backgrounds, socially disadvantaged pupils and education of gifted pupils.

The observed schools occasionally refer to a direct cooperation with the staff from the departments of medicine and social care. A very similar situation is also in the area of help of experts connected to education of gifted pupils. In addition to the above mentioned professional support the starting point for building an inclusive school, is especially cooperation among the educational staff. The talk is about a school principal and a deputy principal for pedagogical activity, teachers (in different functional positions), teacher's assistants (their job is to help teachers with educational activity and communication with pupils and parents, eventually with their community, to support the pupils to adapt to a different school environment, to support the pupils at education and preparation for it, eventually to help pupils with serious disabilities to get to school and school events), pedagogues in a school club and the professional school counseling staff (a special pedagogue, a psychologist, a school counselor, a teacher for prevention).

However, more important is everyday consultation, assistance and cooperation among the teachers and pupils' assistants (if they are in the classroom), cooperation among all the teachers as well as cooperation among the teachers, assistants and professional staff of school counseling departments. Sharing pupils' teaching objectives, finding common strategies of an individual development, exchanging of diagnostic data from the learning process and the best methods of work can help teachers and assistants to find the way to help individuals overcome the difficulties faced by the best possible way.

Relating to the offer, it provided us a complete self-evaluation questionnaire; we selected four criteria for the need of the analysis of the level of cooperation among teachers which include personal aspects and aspects of a process. The personal aspect particularly applies to a desired cooperation among teachers and among teachers and assistants. The aspect of a process presents a global perspective of education, sharing its planning, implementation and evaluation. The chosen criteria are shown in table No. 1. 
Table No. 1: List of criteria assessing the cooperation at school among educational staff

\begin{tabular}{|c|c|c|}
\hline $\begin{array}{c}\text { Number } \\
\text { of item }\end{array}$ & Criterion & $\begin{array}{c}\text { Characteristic } \\
\text { (Guidance questions) }\end{array}$ \\
\hline A 1.3 & $\begin{array}{l}\text { Employees of school } \\
\text { support and help each } \\
\text { other }\end{array}$ & $\begin{array}{l}\text { Do the employees act together with respect } \\
\text { regardless of their role in school? } \\
\text { Does the teaching staff exchange experiences, } \\
\text { information and materials between them- } \\
\text { selves? } \\
\text { Are all the teachers and their assistants invol- } \\
\text { ved into the planning and evaluation of SEP? }\end{array}$ \\
\hline C 1.8 & $\begin{array}{l}\text { Teachers plan, teach } \\
\text { and reflect on their } \\
\text { work in partnership }\end{array}$ & $\begin{array}{l}\text { Do the teachers cooperate in planning les- } \\
\text { sons, preparation of projects and other activi- } \\
\text { ties for pupils? } \\
\text { Do the teachers sometimes teach in teams } \\
\text { (e.g. in pairs, projects, training seminars)? } \\
\text { Do the teachers always use team teaching as } \\
\text { an opportunity for joint reflection on a pupil's } \\
\text { learning? } \\
\text { Do the teachers modify their teaching in re- } \\
\text { sponse to feedback from their colleagues? } \\
\text { Do the teachers, who work together, provide } \\
\text { the pupils with a good example for their co- } \\
\text { operation? } \\
\text { Does the teaching staff solve problems to- } \\
\text { gether, if there are concerns about the state of } \\
\text { a pupil or group? }\end{array}$ \\
\hline C 1.10 & $\begin{array}{l}\text { Are the assistants for } \\
\text { pupils with SEN } \\
\text { involved in planning } \\
\text { the curriculum and its } \\
\text { evaluation? }\end{array}$ & $\begin{array}{l}\text { Do the assistants for pupils with SEN try to } \\
\text { ensure pupils maximally to be the most inde- } \\
\text { pendent on their direct support? }\end{array}$ \\
\hline C 2.1 & $\begin{array}{l}\text { Professional and hu- } \\
\text { man qualities of each } \\
\text { employee are fully } \\
\text { known and utilized }\end{array}$ & $\begin{array}{l}\text { Are the teachers encouraged to further devel- } \\
\text { opment of their knowledge and skills? } \\
\text { Do the teachers offer their special skills and } \\
\text { knowledge to others? } \\
\text { Do the teachers debate the possible origin of } \\
\text { a pupil's problems with each other? } \\
\text { Do the teachers have the opportunity to learn } \\
\text { from practice and experience of their collea- } \\
\text { gues from other schools? } \\
\text { The level of achievement of a specific crite- } \\
\text { rion on a scale is presented in the following table } \\
\text { No. 2. Their own interpretation of the argu- } \\
\text { ments is documented by quotations of the } \\
\text { participating respondents. }\end{array}$ \\
\hline
\end{tabular}


Table No. 2: Quantified evaluation of criteria evaluated the cooperation among educational staff

\begin{tabular}{||c|c|c|c|c|c|c|}
\hline $\begin{array}{c}\text { Number } \\
\text { of item }\end{array}$ & Indicator & Average & Mode & Median & Maximum & Minimum \\
\hline C 1.8 & $\begin{array}{c}\text { Employees of } \\
\text { school support } \\
\text { and help each } \\
\text { other }\end{array}$ & 6.14 & 6 & 6 & 7 & 4 \\
\hline $\begin{array}{c}\text { Teachers plan, } \\
\text { teach and re- } \\
\text { flect on their } \\
\text { work in part- } \\
\text { nership }\end{array}$ & 6.14 & 7 & 7 & 7 & 4 \\
\hline C 1.10 & $\begin{array}{c}\text { Teachers and } \\
\text { assistants for } \\
\text { pupils with } \\
\text { SEN encour- } \\
\text { age and pro- } \\
\text { mote active } \\
\text { learning of } \\
\text { each pupil }\end{array}$ & 5.33 & 7 & 7 & 7 & 2 \\
\hline $\begin{array}{c}\text { Professional } \\
\text { and human } \\
\text { qualities of } \\
\text { each employee } \\
\text { are fully } \\
\text { known and } \\
\text { utilized }\end{array}$ \\
\hline
\end{tabular}

\section{A 1.3 Employees of the school support and help each other}

The cooperation of teachers is based on two lines: the daily co-existence and respect, professional cooperation. This criterion has a relatively high average value of 6.14, it also has a considerable variance in the range 4 to 7 . Smaller rural schools indicate very close cooperation and sharing experiences among all the employees which is also caused by the frequent involvement of the teachers into teaching (especially educational subjects): Creating a common "database" of ideas, suggestions, information, didactic means, pictures, games etc., accessibility for all the teachers. The educational staff plans the Educational Program and prepare the evaluation (each according to their specialization). In daily contact, they exchange experiences, information, materials. If someone attends a course or seminar, he informs the others of the obtained information 
they could use in their work. One urban school states that the teachers prepare "example" lessons for each other. Another large urban school quite critically admits the reserves in this area, which they will try to use by the development of teamwork.

\section{1.8 Teachers plan, teach and reflect on their work in partnership}

This criterion belongs to the group of criteria with mode 7. Its value is from 4 to 7 . Two schools did not present any arguments to its evaluation; other schools cooperate especially during the project days, school events, organisation of the school year, trips, Children's Day and other events. The same type of cooperation is also shared by one urban school. This school is self-evaluated critically by degree 4 and it states that the teachers would like to try team teaching in the future. This school also emphasizes a close cooperation with students of the Faculty of Education, Masaryk University, who attend their school during their school practice. Team teaching sometimes appears only at one school.

\section{1.10 Teachers and assistants for pupils with SEN encourage and promote active learning of each pupil}

This indicator was evaluated as the fourth worst in total. The reason was that only three schools could comment on this evaluation due to having an assistant at the time of making the self-evaluation questionnaire. Although two schools were self-evaluated by the highest degree 7 , any significant arguments for this evaluation were not provided. The third school was evaluated by degree 2 and wants to get more assistants for pupils with special educational needs in the future.

\section{2.1 Professional and human qualities of each employee are fully known and utilized}

In this criterion, all the schools were self-evaluated by the relatively high degree 6 or 7. This corresponds to the average of self-evaluation. Only one school chose the evaluation degree 4 . In the argumentation for their choice of evaluation of schools, they emphasized that all the teachers are supported in further education and have the opportunity, after agreement with the school management, to be educated according to their interests (if their education is connected with needs and philosophy of the school). Some teachers act as tutors in programs of further education of educational staff. Some schools have a system of mentors and they also meet informally. At all the schools they discuss pupils' achievements and problems and they transmit their experience and advice how to solve problems. If necessary, they ask teachers from other schools for help. One school would be very pleased to cooperate closely with other schools. 


\section{B. Cooperation among pupils}

In each class an important role is palyed by the fact, to what extent the mutual assistance among pupils and their cooperation is supported. If pupils carry the responsibility for common results, they learn many cooperative skills, including respect to others. They learn to accept their diversity and use their potential for joint activities.

In the monitored schools it is shown that teachers quite differently perceive the fact that every pupil is different, has different talents, interests and needs. They try to use effectively all personal and social specification of individuals to mutual enrichment of all and also to improve the quality of living together. From the answers it is clear that especially teachers of small schools pay a great attention to cooperation among pupils in the classroom and less to division of work and cooperative learning. They often teach them to cooperate and help each other.

In the self-evaluation questionnaire two criteria selected to an explicit analysis of the level of cooperation among pupils were included. The first one (A 1.2) refers primarily to the axiological dimension of cooperation among classmates and mutual respect for the achievements of the others. The second criterion (C 1.5) monitors the current level of the use of cooperation and mutual assistance in the educational process. The chosen criteria are clearly presented in the table No. 3.

Table No. 3: List of criteria evaluating the cooperation among pupils at school

\begin{tabular}{|c|l|l||}
\hline Number of item & \multicolumn{1}{|c|}{ Criterion } & \multicolumn{1}{c|}{$\begin{array}{c}\text { Characteristic } \\
\text { (Guidance questions) }\end{array}$} \\
\hline A 1.2 & Pupils help each other & $\begin{array}{l}\text { Do the pupils help each other? } \\
\text { Do the pupils understand that from vari- } \\
\text { ous pupils different (maximum) perfor- } \\
\text { mance could be expected? }\end{array}$ \\
\hline C 1.5 & $\begin{array}{l}\text { Do the pupils perceive an offer and use } \\
\text { of assistance from classmates as a com- } \\
\text { mon part of the lesson? } \\
\text { Are there rules established, how to par- } \\
\text { ticipate in a discussion, how to listen and } \\
\text { how to request closer explanation both } \\
\text { from other classmates and from adults? } \\
\text { Are the pupils taught how to build joint } \\
\text { outcomes from the different contributions } \\
\text { of individuals and groups? } \\
\text { Do the pupils share the responsibility for } \\
\text { help to overcome the problems that some } \\
\text { pupils have during lessons? } \\
\text { Are the pupils involved in evaluation of } \\
\text { quality of teaching? } \\
\text { Do the pupils help each other set imme- } \\
\text { diate targets of their education? }\end{array}$ \\
\hline
\end{tabular}


The level of achievement of a specific criterion on a scale is presented in the following table No. 4. Their own interpretation of the arguments is again documented by quotations of participating respondents.

Table No. 4: Quantified evaluation of the criteria evaluated the cooperation among pupils

\begin{tabular}{||c|c|c|c|c|c|c||}
\hline $\begin{array}{c}\text { Number } \\
\text { of item }\end{array}$ & Indicator & Average & Mode & Median & Maximum & Minimum \\
\hline A $\mathbf{1 . 2}$ & $\begin{array}{c}\text { Pupils help } \\
\text { each other }\end{array}$ & 5,7 & 6 & 6 & 7 & 4 \\
\hline C $\mathbf{1 . 5}$ & $\begin{array}{c}\text { Pupils work } \\
\text { together dur- } \\
\text { ing education }\end{array}$ & 5,5 & 6 & 5,5 & 7 & 4 \\
\hline
\end{tabular}

\section{A.1.2 Pupils help each other}

This indicator is one of the lowest evaluated criterions in general. According to the teachers, the pupils help each other, or at least they are encouraged and get enough space. On the other hand, there is no more tolerance for individual performances. Most children understand different performances, but most of them perceive that as an injustice.

According to the filled questionnaires, it is concluded that pupils are encouraged to cooperation and to mutual assistance from the beginning of the school attendance. The pupils usually work in groups in the classroom or in project teaching. The teachers bind the development of mutual help closely to pupils through the form of group work. However, they do not comment any moral profiling of pupils and education of school in general. Only three schools argue they lead pupils to be able to empathize with the feelings and situations of the others. On the contrary, most of the schools apply the forms of personal and social education. They try to lead the pupils to clearly understand the principles of individualization in school and society. This imbalance predicts one of the lowest averages between items 5.7 (value from 4 to 7).

Pupils can better understand the diversity of evaluation based on individual options (disabled, socially disadvantaged or specific learning disabilities). The creation of an uncompetitive environment or free choice of different tasks can also play a very positive role. In small school classes, there are the optimum conditions for cooperation and mutual help of pupils of different age groups. 


\section{1.5 Pupils work together during education}

Also this indicator rangs among the worst evaluated. The teachers in the monitored schools are aware to a different degree that the level of cooperation among pupils is closely linked with the development of their social and personal competencies. From their statements it is clear that they try to pay considerable attention to this issue. Their statements in the questionnaire were supported by arguments aimed at cooperation, mutual assistance and respect for rules of communication in joint activities and in their presentation.

The mentioned difference among schools also brings a considerable variance of the minimum and maximum values (from 4 to 7 ), so it means a relatively low average 5.5. Talking about the undisputed positives, it is clear that in more than half of the schools the pupils perceive the offer and use of assistance from classmates as a common part of their lesson. There are clearly set out rules of communication, especially for a group work.

The half of the schools perceives a systematic leading of pupils to mutual evaluation and self-evaluation as an important sign of cooperation. This applies to activities of both individuals and the whole groups. The most systematic process is chosen by one of the schools, which systematically requires a similar form from all the teachers. It is emphasized that the pupils are involved in mutual evaluation of results and the whole lessons. The mentioned systematization is highlighted by a statement of another school, where the pupils have been taught the rules of communication in a group since the kindergarten.

\section{CONCLUSION}

Among the arguments of schools there are substantial differences related to their degree of specificity. We can say, that currently there is a transition among integration and inclusion in the Czech Republic, which a dimorphic inclusion/ integration describes the best (Lechta, 2010, p. 34).

Some schools justify their evaluation of the criteria through very specific arguments which demonstrate their real life, which is occasionally missed in some schools. Generally we can say that smaller rural schools indicate very close cooperation and sharing experiences among all the employees, which is also caused by the frequent involvement of teachers into teaching. The large urban schools quite critically admit its reserves in this area. In the future these schools want to get more assistants for their pupils with special educational needs. However, the most important thing is to goad and institutionalize special broad cooperation among the teachers.

According to the teachers, the pupils help each other or at least they are encouraged to do so and get enough space. On the other hand, there is no more tolerance for individual performances. Although most children understand that they are different and various performances can be expected for this reason, 
some of them still feel it like an injustice. The task of the teachers is not only to create a safe environment where pupils help each other, but such a learning environment in which results related with diversity are accepted.

We would like to add that during our research close cooperation among participating schools (through mutual visits, observations, exchanging of experience and problem solving) has been developed. All the schools evaluate this fact as a great benefit.

\section{List of literature and professional sources}

Ainscow, M. (1999). Understanding the Development of Inclusive Schools. London: Falmer.

Ainscow, M. et. al. (2000). Reaching out to all Learners: Some Lessons from International Experience, School Effectiveness and School Improvement, Vol. 11, No. 1, pp. 1-9.

Ainscow, M. (2005). Developing Inclusive Education Systems: What are the Levers for Change? Journal of Educational Change, Vol. 6, No. 1, pp. 109-124.

Ainscow, M. et al. (2006). Improving Schools: Developing Inclusion. London: Routledge.

Arnesen, A., Allen, J., \& Simonsen, E. (eds.) (2009). Policies and Practices for Teaching Socio-cultural Diversity. Concepts, Principles and Challenges in Teacher Education. Strasbourg: Council of Europe.

Booth, T. (1981). Demystifying Integration. In W. Swann (ed.) The Practice of Special Education. Oxford: Blackwell.

Booth, T., \& Ainscow, M. (1998). From Them to Us: an International Study of Inclusion in Education. London: Routledge.

Dyson, A. (1990). Special Educational Needs and the Concept of Change, Oxford Review of Education, Vol. 16, No. 1, pp. 55-66.

Booth, T., Ainscow, M. (2002). Index for Inclusion. Developing Learning and Participation in Schools. London: Centre for Studies on Inclusive Education. Retrieved from http://www.eenet.org.uk/resources/docs/Index\%20English. pdf.

Conclusions and Recommendations of the $48^{\text {th }}$ Session of the International Conference on Education (2008). Geneva: UNESCO-IBE. Retrieved from http: //www. ibe. unesco.org/en/ice/48th-ice-2008/conclusions-and-recommendations.html

Janebová-Kučerová et al. (2008). Otevíráni školy všem dětem: Možnosti a přiklady práce se sociálně a kulturně znevýhodněnými dětmi (pilotní verze). Praha: O.S. AISIS.

Key Principles for Promoting Quality in Inclusive Education - Recommendations for Practice. (2011). Odense: European Agency for Development in Special Needs Education.

Kratochvílová, J., Havel, J., \& Filová, H. (2009). Sebehodnocení inkluzivního prostředí na 1. stupni základních škol. Brno: Masarykova univerzita. 
Kratochvílová, J., Havel, J., \& Filová, H. (2011). Analýza školních vzdèlávacích programů jako prostředek kvalitativního rozvoje inkluze na 1. stupni $Z \check{S}$. Brno: Masarykova univerzita.

Kratochvílová, J., Havel, J. (2012). Index for Inclusion in the Czech Primary Schools. Teachers Self-evaluation in Primary Schools. Research. Brno: Masaryk University.

Lechta, V. (2010). Základy inkluzivní pedagogiky. Praha: Portál.

Obiakor, F. E. et al. (2012). Making Inclusion Work in General Education Classrooms. Education and Treatment of Children, Vol. 35, No. 3, pp. 477-490.

O'Hanlon, Ch. (2003) Educational Inclusion as an Action Research: an Interpretive Discourse. Milton Keynes: Open University Press.

Peters, S. J. (2004). Inclusive Education: an EFA Strategy for All Children. New York: World Bank. Retrieved from http://www.wds.worldbank.org/external/default/ WDSContentServer/IW3P/IB/2005/01/12/000090341_20050112093220/Rendered/PDF/311950PAPER0In1fa1strategy01public1.pdf

Policy Guidelines on Inclusion in Education. (2009). Paris: UNESCO.

Watkins, A. (2009). Assessment in Inclusive Settings across Europe: the Paradigm Shift Towards Assessment for Learning. In M. Vítková \& V. Vojtová (eds.), Education of Socially Disadvantaged Pupils across Europe (p. 79-102). Brno: Masaryk University.

\section{Contacts:}

Mgr. Jiří Havel, Ph.D.

Mgr. Jana Kratochvílová, Ph.D.

Department of Primary Education

Faculty of Education, Masaryk University

Poříčí 31, 60300 Brno

Czech Republic

E-mail: havel@ped.muni.cz, Phone: +420 549491674

E-mail: kratochvilova@ped.muni.cz, Phone: +420 549495216 